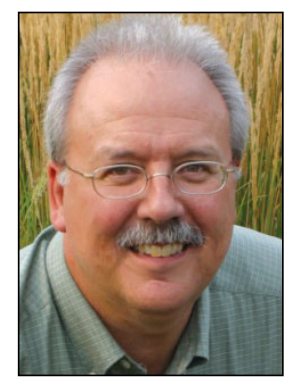

\author{
MetRICS FROM THE FIELD \\ Blending insights from research with insights from practice \\ Ken Meter
}

\title{
Designing food to suit our infrastructure?
}

L ast summer during harvest season, I descended to a hotel lobby in South Carolina eager for a good breakfast. I had just visited vast orchards down the road where peaches were being packed for shipment, and I had seen plentiful local

Minneapolis-based Ken Meter is one of the most experienced food system analysts in the U.S., having produced more than 100 state and regional studies of farm and food economies in 36 states, including (with Megan Phillips Goldenberg) Making Small Farms into Big Business, a US\$9.8-million investment plan for local foods commissioned by the state of South Carolina, and a forthcoming review of economic impacts of institutional food purchasing compiled for the Illinois Public Health Institute and the U.S. Centers for Disease Control and Prevention. Meter is now part of a national team devising a toolkit for measuring economic impacts of food business clusters. cantaloupe at roadside stands — but the breakfast buffet featured neither of these products. Unripe melon with almost no flavor, grown in a distant place, filled a large bowl. It was what the supply truck had brought in.

When I arrived at the grocery later that day, the local peaches on sale were gorgeous - but not yet ripe. The grocery supplier delivered the same hard peaches that it ships to distant customers. As I spoke with local food leaders about this curiosity, I was told it was difficult to source local food in the state because competing suppliers shipped bountiful quantities of fresh produce from Florida, Georgia, and North Carolina from established, large farms. Due to seasonal harvest schedules, these often arrived just before, or just after, South Carolina producers could ship. Distributors said it was so easy to simply keep shipping from distant sources that the local product often never reached 
the shelves. Buyers were content to purchase Florida produce and call it "local," since they had purchased it from a local wholesaler.

I gained deeper perspective on this, however, when I spoke with some investors in Florida who asked me to assist them with a local food plan. Motivating their interest was a different curiosity: amidst produce farms that shipped food north, much of the produce they found at local stores was coming from Costa Rica. This group wants to invest in creating new local market channels.

Some of these ironies can be explained by price theory: most buyers will look for the lowest price available, all else being equal. In a world where melons and peaches have become standardized commodities, the lower costs of land and/or labor in Costa Rica trump Florida produce grown in Florida, while the lower costs of production in Florida trump South Carolina produce grown in that state. Seasonal availability also plays a role since market prices are often higher at the front end of the season, when people are eager to eat a product that is not yet being harvested in their neighbors' fields.

Yet the curious cases of mobile melons and pre-ripe peaches also reflect a design principle in the food industry itself. We are now designing food that suits our infrastructure, rather than designing infrastructure that handles the foods we've evolved to enjoy. We've selected produce varieties that have good storage qualities - often a thick skin and relatively stable shelf life - and thus we've limited consumer food choices, distorted markets, and reduced biodiversity. It is possible, for example, to grow up in South Carolina not knowing what a truly tree-ripened peach tastes like, since the fruit is harvested early for better shipping.

This rumination led me back to the work of William Cronon, one of my heroes in describing the complex interplay of food, economics, politics, and society. In his massive work, Nature's Metropolis (Cronon, 1991), Cronon shows how the metropolitan region of Chicago was fundamentally shaped by the development of several overlapping industries: grain, lumber, meat, railroads, credit, and others. While each of these products has its own "supply chain," each industry interacts with the others as well.

One memorable story is Cronon's description of the evolution of the design of beef. When Chicago was a young city, live animals were often shipped by barge to major cities for slaughter at the outskirts of town. Consumers generally considered only fresh meat to be healthy to eat - and anyway few owned freezers.

Cronon outlines how the advent of rail travel created a newly designed product. Beef carcasses could now be processed closer to the farm and shipped in ice-cooled cars by rail to major markets like New York. Moving the carcass from the farm to the retail counter might take a week or more.

Consumers at first balked at the idea of buying beef that was so old. So the new industry marketed the concept that aged beef would be a better product, with better flavor. Eventually, aging took hold as a premium consumer attribute.

Yet the most dramatic shifts were yet to come. As industrial growing methods gained strength, grain was modified so that it was more standardized, higher in protein content, and yielded more bushels per acre. Commodity grading techniques allowed distant buyers to trade grain at great distances without actually seeing the product. This separated ownership of the grain from physical possession, reducing the importance of farmers who had up to then shipped grain in fifty-pound bags labeled with their own name. When this grain that was selected to grow prolifically was in turn fed to cattle that had been selected to gain weight 
as fast as possible, animals grew more rapidly, with greater consistency, and were larger in frame. ${ }^{1}$

By the 1970s, further efficiencies were created west of Chicago and outside Cronon's scope. Larger processors calculated that shipping beef carcasses by semi truck (now the main transport device) was inefficient because carcasses came in irregular sizes, leaving empty space in each trailer. One firm began shipping cut, boxed beef. Since each box was packed tightly and boxes could be stacked on each other to fill the entire trailer, each truck hauled about as much meat as possible, with little wasted space. This reduced shipping costs, created a competitive advantage to the early adopters, and moved processing into the hands of the aggregators.

Yet this approach also pushed price margins for raising cattle far below what most family farms could endure. After 1979, the number of farms raising cattle, and farmgate sales, steadily fell until U.S. cattle sales bottomed out at US $\$ 44$ billion in 2009 (USDA ERS, n.d.). Then new consumer interest in quality meats, combined with producers passing along the costs of higher grain prices when they could, nudged sales levels upward.

Data from the U.S. Department of Agriculture's Economic Research Service (ERS) Food Availability reports show that per capita consumption of retail beef in 2012 (57 pounds or $26 \mathrm{~kg}$ ) was about the same as it had been in 1909 (59 lb. or $27 \mathrm{~kg}$ ), after peaking at $94 \mathrm{lb} .(43 \mathrm{~kg})$ in 1976 (ERS, 2014a). Total consumption in pounds edged downward even as population rose. The average carcass today produces a lower ratio of meat than it did in 1909 (79 percent to 70 percent); consumers were more likely then to eat organs, tongue, and other products, and perhaps animals

\footnotetext{
${ }^{1}$ Although this is not a theme Cronon addresses, we need more research on this question: Does the fact that we are maximizing weight gain in our livestock have anything to do with the fact that humans are also gaining more weight?
}

carried less fat. The farmer-to-wholesaler price spread has eroded, from 12 percent of the retail price in 1970 to 5 percent in 2013, while the wholesale-to-retail price spread doubled, from 22 percent in 1970 to 43 percent in 2013 (USDA ERS, 2014b). Many Midwestern communities have lost their cattle farmers. This has resulted in a cumulative decline in the number of residents holding farming, processing, and land management skills, as well as a reduction in the power of local communities to choose what they eat.

This seems to be the prevailing paradigm of efficiency: Aggregators with power in the marketplace design beef that ships at lower costs and build commensurate systems for conveying it to markets. This reduces prices and margins and thereby runs farmers out of business, weakening rural communities. Consumers cut back consumption but pay more and more to support the retail food delivery system.

As I wrote this column, I spoke with a meat consultant who was not aware that I was preparing this essay. This expert volunteered that the margins are so low in the large-scale industry that "meat has so little value it is almost like a byproduct of the industrial process." Larger profits are made selling hides, offal, blood, and other items that are "waste" to smaller-scale plants.

Meanwhile, my body has multiple ways of informing me that I am healthier if I consume grass-fed beef purchased directly from a local butcher. It is not altogether content with the medium-scale grass-fed varieties that are increasingly available at the stores, but I am glad this alternative is emerging.

Designing the foods we eat to fit the infrastructure we choose to use creates disruptions in the marketplace and challenges to health, but it is supported in current economic thinking because a firm with market power has found ways to make better use of its resources. Through tax incentives and subsidies, we reward firms for moving in this 
direction. Yet creating efficiency for the firm is different than creating the most efficient food system; what looks efficient from a community standpoint (e.g., wanting lots of farmers, their skills, their work habits, and their children to stay in the community) is often different than the efficiencies of the firm.

In reality, as in Cronon's Chicago, the supply system is an interlaced network of relationships, not a series of independent, single chains. Over time, if we choose to embrace this complex reality, fruits and meats that were designed for longdistance shipping may fall into disuse. We may, indeed, develop the technology, infrastructure, and value networks that make it easier and more efficient to ship fragile, ripe fruit and quality meats shorter distances. We may choose to adopt tax and investment policies that favor short supply networks. We may even share with youth the joy of peach juice running down our chins.

\section{References}

Cronon, W. (1991). Nature's metropolis: Chicago and the Great West. New York: W. W. Norton.

USDA Economic Research Service [ERS]. (n.d.). Annual cash receipts by commodity, 2010-2014F. Retrieved from http://www.ers.usda.gov/dataproducts/farm-income-and-wealth-statistics/ \#.U s6A6PWi9U

USDA ERS. (2014a). Food availability: Red meat (beef, veal, pork, lamb, and mutton) [Data set]. Retrieved from http://www.ers.usda.gov/datafiles/Food Availabily Per Capita Data System/Food Availability/mtredsu.xls

USDA ERS. (2014b). Historical monthly price spread data for beef, pork, broilers [Data set]. Retrieved from http://www.ers.usda.gov/data-products/ meat-price-spreads\#.U s7mKPWi9U 